\title{
定置漁場の遠隔計測の試み*1
}

\author{
小長谷庸 夫
}

(1979 年9月 12 日受理)

\section{A Trial Method to Telemetry of the Setnet Fishing Ground \\ Tuneo KonAgA YA*2}

The change of water temperature in the setnet fishing ground was measured on a small type telemetry system. In this system, signals of water temperature were transmitted as FM-FM radio waves and the signals received were discriminated and recorded at the base on land. The behavior of fish which entered the bagnet of the setnet was observed with a set of telesounders which was installed at the entrance of the bagnet in water.

During these observations, the water temperature in the setnet fishing ground rose suddenly and the echoes of yellowtail Seriola quinqueradiata entering the bagnet appeared.

From the above fact, it was suggested that there was a close relation between the change of water temperature and the approaching behavior of the yellowtail to the coast.

漁場の環境と魚群の接岸や入網時の生態などとの関連 を明らかにする事は，沿岸漁業の振與を計るために極め て重要である。特に漁場が限定された現在，沿岸漁場八 の来遊魚に対する依存度が堌しつつあり，漁場や魚群の 生態についての基礎的な研究がまたれる。

従来，定置漁場などの漁況要因は，主として漁獲高 や, 気象や海況の統計的な処理 ${ }^{1,2)}$ ，なは水温や塩分量 などの自記記録計*』などによつて検討されるる゙あいが多 加た。

しかし，刻々の環境の変化や入緝状況などを観測出来 孔ば上檤の関連も明らかになり，定置漁場の設定や漁具 設計上の重要な知見を得ることが出来よら。

そこで定置漁場で手軽に使用出来る水温の遠隔計測用 のブイ（以下湘温ブイといら）を試作して試験し，あわ せて定置網用テレサウンダー*4 (以下遠隔魚探㙨といら) の魚群像および潐獲結果などを検討した結果二三の知見 を得たので報告する。

\section{実 験 方 法}

三重県の片田漁場は，熊野灘の有数な定置漁場として 知られている。この漁場は外洋水之伊勢湾加らの内湾水 の流路にあたるため, 両者の水塊の交代も激しく，对象 魚の種類も多い。また事務所から漁場までの距離が短い
ため，屋上の見張り台から直接漁場を眺望出来る。その 上，この漁場には遠隔魚探機が設備され，刘々の入網状 況が観測されている。したがつて，更に表面水温たどを 連䋶的に遠隔計测出来九瀂群が接岸し，入網した時の 海況状況を明らかにすることが可能になる。

そこで Fig. 1 に示す测温ブイを作つて連続観測を試 みた。片田漁場は全国であむれにみる急潮漁場の一つ で3 漁具は潮流によつてしばしば水面下に沈下するので 湘温ブイには十分な䩂王性が要求される。そこでブイの 本体はプロパンガス容器を改造して作り， $7 \mathrm{~kg} / \mathrm{cm}^{2}$ ま で内玨を加えてフランジ部のパッキンの漏水デストを行 つた。

水温掅報はサーミスター (32B1 型, $2 \mathrm{k} \Omega$ at $25^{\circ} \mathrm{C}$, $\left.-3.9 \% /{ }^{\circ} \mathrm{C}\right) 2$ コを用い, ウイーンブリッジ型 $\mathrm{RC}$ 発振

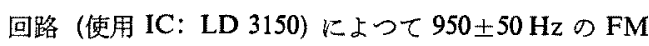
信号に変換し, FM 送信機によつて送信した。 ここで，RC 発振回路と感鼬部のサ一ミスターは一体 化し，可能な限り小型化した。またこの回路はブイの下 部に突出した 3 本の亦汹込式の円简型の脚（内径 20 $\mathrm{mm}$, 外径 $29 \mathrm{~mm}$, 長さ $80 \mathrm{~mm}$ ) の一本の内部以封入 し,サーミスターを円简の内部に接着して感度を向上さ せだこの回路に供給する電源はトランジスタ式の定電 王回路を用いて一定電圧に保つた。

*1 研究費の一部は 1974 年度文部省科学研究费（研究課題：計測に上る漁場環境の研究）によって行った。

*2 三重大学水産学部 (Faculty of Fisheries, Mie University, Edobashi, Tsu 514, Japan).

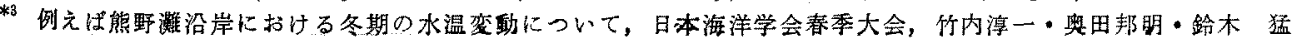
(1975).

*4 TS-12 KM 型 
ブイの上部には高さ $1.85 \mathrm{~m}$ の $1 / 4$ ホイップフンテナ を立てた。またブイは運動場側の台浮子付近の側張りに 四方からロープで張つて固定した。

送信には $40.68 \mathrm{MHz}$ の無免許の区別 B の電波*1を用 いた。信号の受信は，陸上基地において行つた。その方

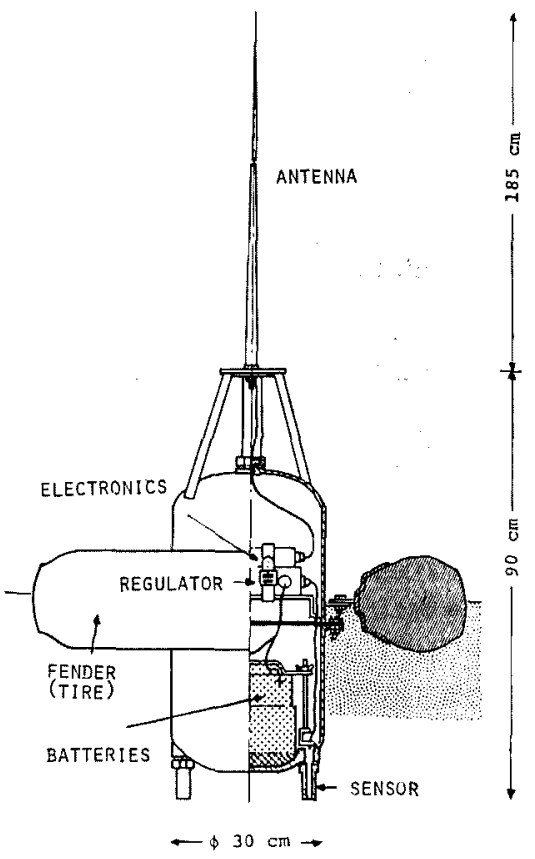

Fig. 1. Sectional diagram of the telemetry buoy.
法は，高さ約 $8 \mathrm{~m}$ の屋上に 3 ェレメント垂直偏波用の 八木アンテナを設蒖し，水晶制御 FM ダブルスーパー 受信機で受信し，出力の AF 信号 $(950 \pm 50 \mathrm{~Hz})$ 注雅 音をリミッタで除いた後複同調方式の FM 検波器によ つて復調した。

奏踰に用いた送受信機は $60 \mathrm{MHz}$ の市民バンド用の 回路*2の周波数を变更し，かつ送信出力を落して用いた。 測温回路，リミッタ，および FM 復調回路は自作した。 実駼に用いた装置のブロックダイヤグラムを Fig. 2 に 示す。

温度信号の出力は, 高感度記録計 (EPR-2T 型)で記 録し，同時に遠隔魚探機の記録と対照した。また洞起し 時にはブイの付近で海洋観測を行つて水温の記録を険討 し，同時に海水を採取して塩案量す浿つた。

観測は 1974 年 12 月 26 日から 1975 年 1 月 4 日 まで行ない,その後更にブイの改良試驗む行つた。

\section{結 果}

RC 発振回路の発振周波数は，IC お゙よびコンデンサ 一などの温度特性によつて周囲温度の影響を受け易い。 そこで湘温用サーミスターを $2 \mathrm{k} \Omega$ の固定抵抗に固き喚 えて周囲温度の変化に伴う発振周波数の誤差を調べたと ころ，この値は温度 $1^{\circ} \mathrm{C}$ あたり約 $9 \mathrm{~Hz}$ であつた。し かし電子回路とサーミスターを一体化したことによつて この誤差を無視することができた。この回路を封入した 脚部は 鉄製で熱容量が大きく，温度追従性はかなり悪 い。水温 $15^{\circ} \mathrm{C}$ 儿於いて約 $1^{\circ} \mathrm{C}$ の温度変化に対し約 1 分 の痋れがみられた。

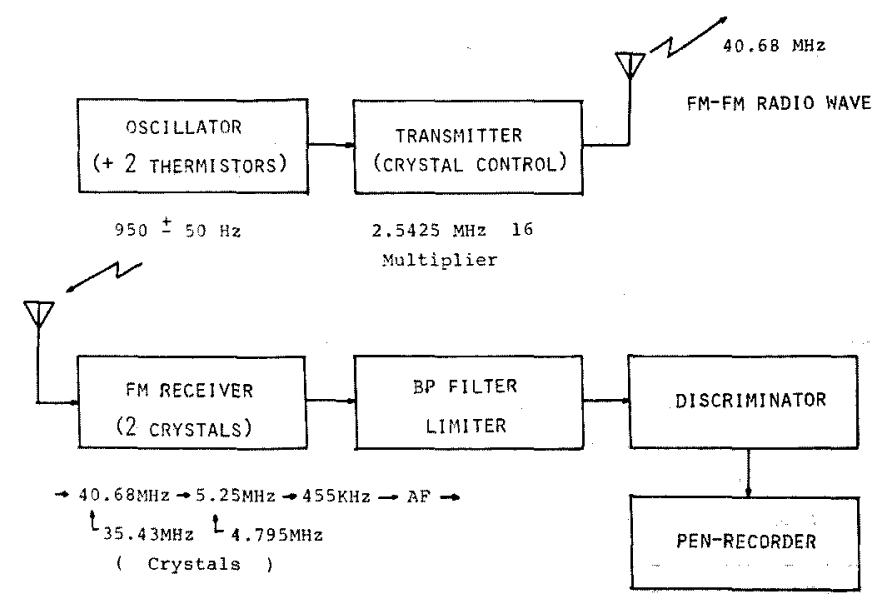

Fig. 2. Block diagram of the telemetry system.

*1 $500 \mathrm{~m}$ で $200 \mu \mathrm{V} / \mathrm{m}$ 以下の電界強度。

*2 チューナー: RF2V4 型, FM 検波：RF-2I14 型, 迭信機：VF-IC9B 型 (三協電機)。 
【磦準水銀温度計によつて校正した水温と受信記録との

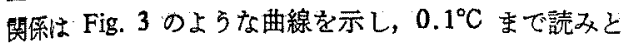
る事が出来た。

受信臨の電界強度は䍩弱電波による到澾距離の限界に 近い。いし測温ブイが海上の見通し線上にありかつ 受信位置す高く，加うるに都市雑音が少ないため信号の 受信状況は荒天時を除いてほぼ良好であつた。

测温ブイを設置した後 2 日間の海況は静稳で，表面水 温法波浪汇上る表層水の混合に上ると思われる微細な変 動を伴ないつつ $15.2^{\circ} \mathrm{C} \sim 15.6^{\circ} \mathrm{C}$ の範围で帄るやかに上 下した。

12 月 27 日 11 時 55 分頃, 水温は $15.4^{\circ} \mathrm{C}$ から $15.8^{\circ} \mathrm{C}$ 几急変し，約 20 分後遠隔魚探機に入網像が現われた。 これらの記録を Figs. 4, 5 に示す。

弯た夕持 (14 時) の漁獲の主体は Table 1 に示すよ

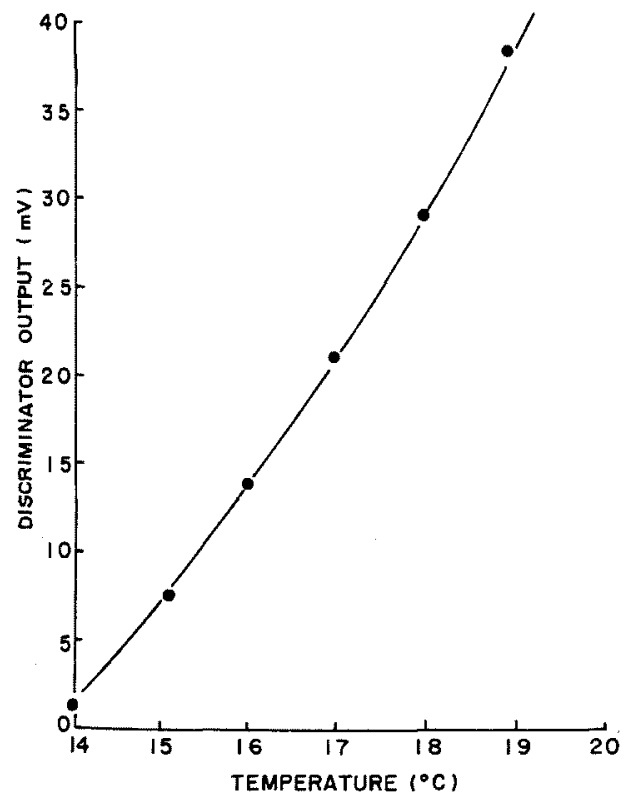

Fig. 3. Relation between the water temperature and the output voltage of the discriminator.
らにワラサ Seriola quinqueradiata $1969 \mathrm{~kg}$ (約 500 尾) であつた。同日 22 時ごらより水温の上昇と信号の断続 が起り，28 日 5 時 55 分飞完全心送信が停止した。朝 持 (7 時 10 分) に法運動場側の台浮子々共に㵋温ブイ は䄪 $3 \mathrm{~m}$ 沈下し，以徭急潮之荒天のため 8 日間完全に 海面下に没しその間操業は行なわれなかつた。浮上後は 剆温ブイ内への浸水によってその機能は停止した。

$$
\text { 考察 }
$$

ブリの漁蒦と気象や海況条件との関連を統計的に処理 した結果によると1)，熊野灘の漁獲の山の6割から8割 は低気压通過の直前から直後へか子て現九低気压通過の 前日すでに水温が上昇しているばあいが多い。また低気 生の通過に伴なつて急潮が発生することが多いから， 低気圧や急潮とブリの入網との関係についても古くから 閔心方払学れてきだ。

一例にすぎないが，現場観測中，水温の急昇の直後ワ ラサの大群が入網した事が確誌され，乙れに続いて荒天 と急潮の発生をみた事は上述を実証するものといえよ 亏。

一般に䁔流が沖合から迫り，沿岸水との間に構成され る潮境が沖からよせてくる様な海況です沖合水が接岸す る時6)，好漁が期待出来ると云われているが，刻々の水

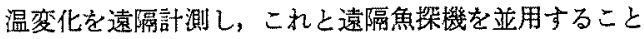
によつて定置漁場付近の水塊の移動と魚群の入網との関 係についてかなり正確な知見を得る事が可能である事は 上述の結果からも肯定されよう。

急潮時の網漁具の沈下水樑を正確に推定する事は困鞾 である。しかし過去に行なわれた模型実驗や現場観測の 結果 ${ }^{7,8)}$ では，土俵の移動が生じない限度に批りる網漁 具の最大沈下深度は水深の 0.7 程度であり, 片田で観

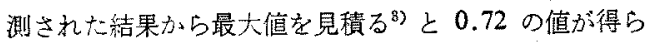
れる。したがつてこの時のブイの沈下深度は水深が $58 \mathrm{~m}$ であるから最大䄪 $40 \mathrm{~m}$ であつたと仮定すると $7 \mathrm{~kg} / \mathrm{cm}^{2}$ の静化に耐えたこのプイには約 1.5 倍の安全度が見込 まれることになる。このブイが急潮によつて沈下して容 易に浸水した原因は次の理由によると思われる。即ち急 潮で沈下した時漁曼は流速の变陲や, 漁具の周团の渦流

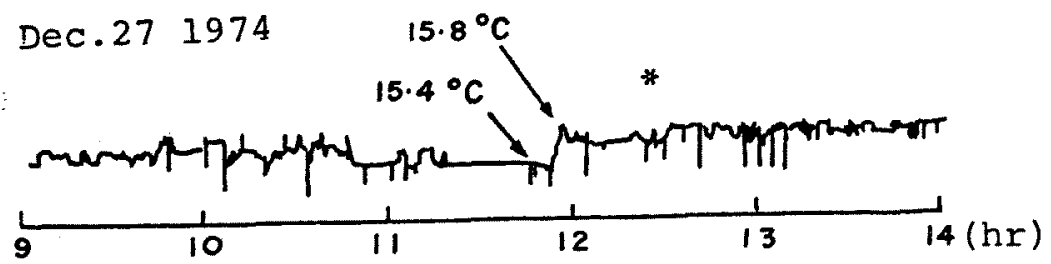

Fig. 4. Change of water temperature in the setnet fishing ground. * Time appared the echo patterns of the fish entering the bagnet. 
Table 1. The catches of fishes by the setnet and sea condition of the fishing ground

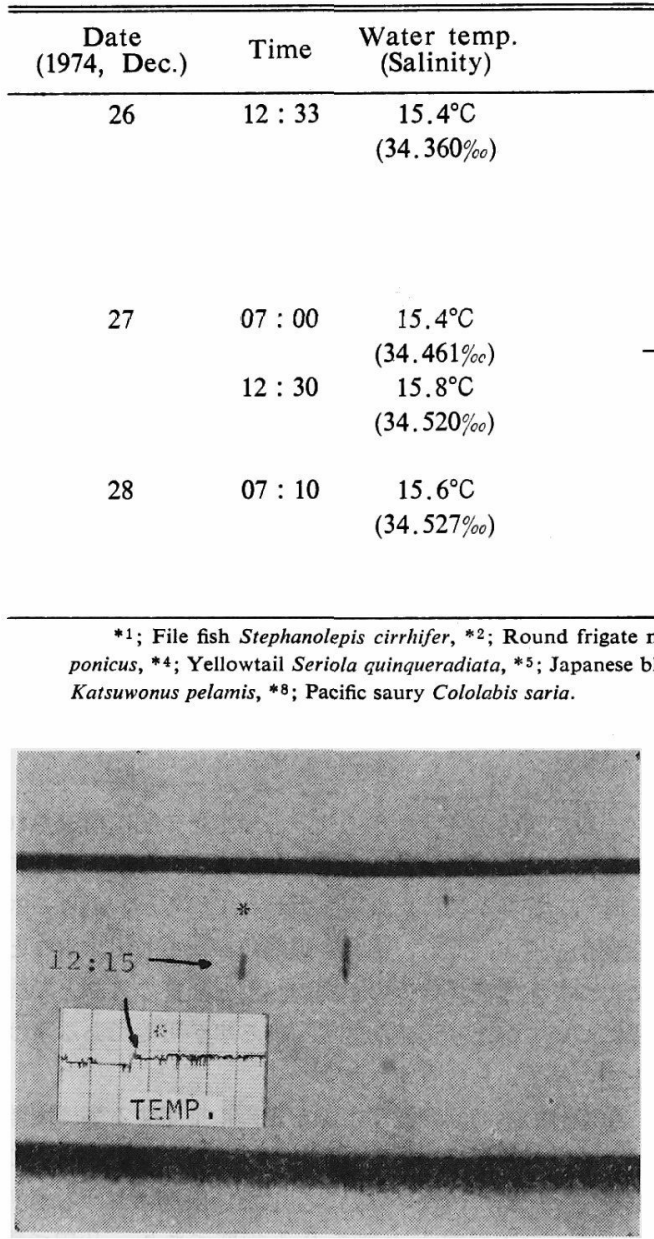

Fig. 5. The echo patterns of the yellowtail entering the bagnet.

などにより上下動するであろう。したがつて漁具と共に 上下動するブイに働らく外圧もた竞ず変化するから，ハ ッキンのゴムは弾性昰によつて防水ぶ不完全になり，そ の機能を失なつたのであろう。このブイの電池（鉛蓄電 池 $38 \mathrm{AH})$ の寿命は, 電圧の低下を考慮すると約 5 日 であつた。したがつて長期観測を行ならばあい電池の交 換にかなりの労力が伴なら。そこでこれらの欠点を除く ため, パッキンを “ $\mathrm{O} ”$ リンクにかえ, 電池ケース（延 綶用標識灯改造）を別に設けて行なつた改良試験では設 置後間もなく荒天になり, 以後急潮によつて台浮子と共 に沈下した。この間ブイの内部への浸水は防ぐ事が出来 たがブイ本体と電池ケースの相互運動によつてアンテナ
が破損し, 電源用のキャプタイヤコードの被覆は摩耗し た。この結果からみると, ブイの形状は単純化し, 単体 で用いるのが好ましい。また，電源にはリチューム電池 など大容量の電池を用い, かつ低電力消費の IC タイ、 一などによつて断続観測させて電池の消耗を防ぐことも 必要であろう。

この様な計測にあたつて数層の水温情報を得る事が出 来れば好ましい。また漁場では流速の遠隔計測に対する 要望も大きい。定置漁場などの流速測定用のテレメータ ーシステムについてはすでに佐々木日) らによつて試作さ れているが，定置漁場で長期間観測するためには荒天或 いは急潮に 耐えかつ保守の容易な 構造のものが望まし い。

試作測器には FM-FM 方式を用いたが IC の発達に よりデジタル化して小型で信頼性の高い回路も自作する 事が容易になつた。またマイクロコンピューターにより 長期間数種のデーターを自動的に補正して印字する事も 可能である。今後数層の水温と流況の多重測定を行い更 にバイオテレメトリー標識魚の追跡実験*を行う事によ り漁場の環境および魚群生態の解析を進めたい。

終りにこの研究を始めるにあたつつて有益な御助言を賜 わつた三重大学水産学部助教授野沢靖氏, 研究にあたつ て御便宜を賜わつた片田定置漁業組合長川端弘太氏はじ め藤内善氏氏，船長の各位，並びに実験の御助力をいた だいた三重県立大学卒業生, 藤州祐次; 松本茂樹の両氏 に厚く御礼申し上げる。

*3 個のソノブィによる超音波標識魚の位置決定, 日本水産学会秋季大会発表, (1978). 
文

献

1) 宫本秀明 - 野村正恒 - 野沢 靖：東海水研報， No. 8, 1-22 (1954).

2) 三谷文夫：日水誌，20，89-95 (1954)

3) 宫本秀明 - 余座和征：日水誌，41，953-956 (1975).

4) 宇田道隆：日本海洋学会誌, 9, 15-22 (1953).

5) 宇田道隆：海洋漁場学, 第 1 版, 恒星社厚生閣, 東京, 1960 , p. 254.
6) 宮崎千博：沿岸近海漁業，第 1 版，恒星社厚生 閣，杲京，1960，p. 243.

7) 小長谷筆夫：三重県大紀要，8(3)，209-296 (1971).

8) 宮本秀明：定道網漁論，第 1 版，河出書房，東 京, 1952, pp. 135-160.

9) T. Sasaki, S. Watanabe, G. Oshiba, and N. OKami: Sci. Papers I.P.C.R., Tokyo, 56, 69-76 (1962). 